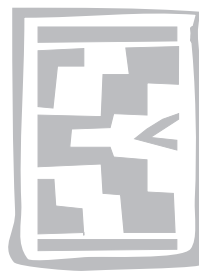

\title{
A century of tick taxonomy in South Africa
}

\author{
I.G. HORAK \\ Department of Veterinary Tropical Diseases, Faculty of Veterinary Science, University of Pretoria \\ Onderstepoort, 0110 South Africa
}

\begin{abstract}
HORAK, I.G. 2009. A century of tick taxonomy in South Africa. Onderstepoort Journal of Veterinary Research, 76:69-74

Eighty ixodid tick species, 25 argasid tick species and Nuttalliella namaqua occur in South Africa. Twenty-one of the 80 ixodid species and two of the argasid species occur only in this country, while $N$. namaqua is present only in South Africa and Namibia. Forty-six of the 80 ixodid species and 16 of the 25 argasid species as well as $N$. namaqua have been described as new species since 1908 . People working in South Africa have written or contributed to the descriptions of 24 of these 63 new species, while foreign researchers have described the remainder. New species indigenous to South Africa are still being discovered, while the names of some species, well known because of their veterinary importance, have been altered.
\end{abstract}

\section{CONTEXT}

The most recently compiled world list of valid tick names contains the names of 692 ixodid and 186 argasid tick species as well as that of Nuttalliella namaqua, the only species in this genus (Nava, Guglielmone \& Mangold 2008). Of these 879 species, 80 ixodid and 25 argasid species and $N$. namaqua occur in South Africa. Twenty-one of the 80 ixodid species and two of the argasid species have distributions confined to this country (Theiler 1962; Walker 1991; Walker, Keirans \& Horak 2000), and $N$. namaqua has only been recorded in South Africa and Namibia. Forty-six of the 80 ixodid and 16 of the 25 argasid species and $N$. namaqua have been described since 1908, and this review is confined to the latter 63 ticks. Twenty-four of these descriptions were written, or contributed to by people in South Africa, and the remainder by researchers in England, France, Germany, Israel, Russia, Mozambique and the USA.

The South African authors and the South African ticks that they have described as being new to sci- ence since 1908 are summarized in tabular format. A similar format has been followed for tick species with South African distributions, but described by foreign researchers during the same period.

The earliest description of a tick that has a strictly South African distribution is that by De Geer in 1778 for Amblyomma sylvaticum, a tick of tortoises and more particularly the angulate tortoise, Chersina angulata (Horak, McKay, Henen, Heyne, Hofmeyr \& De Villiers 2006). The most recent description is that of Haemaphysalis colesbergensis, a tick of domestic and wild felids (Apanaskevich \& Horak 2008c).

South Africans have in recent times also been involved in some of the more controversial name changes of well-known ticks of veterinary importance. The name changes of the common blue tick, Boophilus decoloratus and the Asiatic blue tick Boophilus microplus to Rhipicephalus (Boophilus) decoloratus and Rhipicephalus (Boophilus) microplus were first published by Horak, Camicas \& Keirans (2002) in their world list of valid tick names. 
A century of tick taxonomy in South Africa

TABLE 1 Authors who have worked in South Africa and the South African tick species that they have described as new to science since 1908

\begin{tabular}{|c|c|}
\hline South African author and species & South African author and species \\
\hline Bedford, G.A.H. (1912-1938) & Walker, Jane (1966-2000) \\
\hline $\begin{array}{l}\text { Argas peringueyi (Bedford \& Hewitt 1925) } \\
\text { Rhipicephalus theileri Bedford \& Hewitt, } 1925 \\
\text { Haemaphysalis cooleyi Bedford, } 1929 \\
\text { Ixodes elongatus Bedford, } 1929 \\
\text { Nuttalliella namaqua Bedford, } 1931 \\
\text { Argas striatus Bedford, } 1932 \\
\text { Rhipicephalus distinctus Bedford, } 1932\end{array}$ & \multirow{5}{*}{$\begin{array}{l}\text { Haemaphysalis hyracophila Hoogstraal, Walker \& Neitz, } 1971 \\
\text { Argas africolumbae Hoogstraal, Kaiser, Walker, Ledger, } \\
\text { Converse \& Rice, } 1975 \\
\text { Ixodes neitzi Clifford, Walker \& Keirans, } 1977 \\
\text { Rhipicephalus zambeziensis Walker, Norval \& Corwin, } 1981 \\
\text { Ixodes catherinei Keirans, Clifford \& Walker, } 1982 \\
\text { Ixodes corwini Keirans, Clifford \& Walker, } 1982 \\
\text { Rhipicephalus lounsburyi Walker, } 1990 \\
\text { Rhipicephalus neumanni Walker, } 1990 \\
\text { Rhipicephalus exophthalmos Keirans \& Walker, } 1993 \\
\text { Rhipicephalus oreotragi Walker \& Horak, } 2000 \\
\text { Rhipicephalus warburtoni Walker \& Horak, } 2000\end{array}$} \\
\hline Du Toit, R. (1929-1964) & \\
\hline Rhipicephalus glabroscutatum Du Toit, 1941 & \\
\hline Theiler, Gertrud (1940-1983) & \\
\hline \multirow{3}{*}{$\begin{array}{l}\text { Argas eboris (Theiler, 1959) } \\
\text { Ixodes drakensbergensis Clifford, Theiler \& Baker, } 1975 \\
\text { Rhipicephalus arnoldi Theiler \& Zumpt, } 1949\end{array}$} & \\
\hline & Horak I.G. (1974-present) \\
\hline & \multirow[t]{3}{*}{ Haemaphysalis colesbergensis Apanaskevich \& Horak, 2008} \\
\hline Zumpt, F. (SA Institute of Medical Research) (1948-1980) & \\
\hline Rhipicephalus muehlensi Zumpt, 1943* & \\
\hline
\end{tabular}

* Zumpt was working at the Bernard Nocht-Institut in Hamburg at the time he described this species

TABLE 2 Tick species with South African distributions described as new to science by foreign researchers since 1908

\begin{tabular}{|c|c|}
\hline Tick species and foreign authors* & Tick species and foreign authors* \\
\hline \multicolumn{2}{|l|}{ Ixodid ticks } \\
\hline $\begin{array}{l}\text { Amblyomma nuttalli Dönitz, } 1909 \\
\text { Haemaphysalis aciculifer Warburton, } 1913 \\
\text { Haemaphysalis hoodi Warburton \& Nuttall, } 1909 \\
\text { Haemaphysalis pedetes Hoogstraal, } 1972 \\
\text { Haemaphysalis silacea Robinson, } 1912 \\
\text { Haemaphysalis zumpti Hoogstraal \& El Kammah, } 1974 \\
\text { Ixodes alluaudi Neumann, } 1913 \\
\text { Ixodes aulacodi Arthur, } 1956 \\
\text { Ixodes bakeri Arthur \& Clifford, } 1961 \\
\text { Ixodes bedfordi Arthur, } 1959 \\
\text { Ixodes cavipalpus Nuttall \& Warburton, } 1908 \\
\text { Ixodes myotomys Clifford \& Hoogstraal, } 1970 \\
\text { Ixodes procaviae Arthur \& Burrow, } 1957 \\
\text { Ixodes rhabdomysae Arthur, } 1959\end{array}$ & $\begin{array}{l}\text { Ixodes spiculae Arthur, } 1956 \\
\text { Ixodes spinae Arthur, } 1958 \\
\text { Ixodes theilerae Arthur, } 1953 \\
\text { Ixodes transvaalensis Clifford \& Hoogstraal, } 1966 \\
\text { Rhipicentor bicornis Nuttall \& Warburton, } 1908 \\
\text { Rhipicentor nuttalli Cooper \& Robinson, } 1908 \\
\text { Rhipicephalus evertsi mimeticus Dönitz, } 1910 \\
\text { Rhipicephalus follis Dönitz, } 1910 \\
\text { Rhipicephalus gertrudae Feldman-Muhsam, } 1960 \\
\text { Rhipicephalus simpsoni Nuttall, } 1910 \\
\text { Rhipicephalus sulcatus Neumann, } 1908 \\
\text { Rhipicephalus turanicus Pomerantsev, } 1936 \\
\text { Rhipicephalus zumpti Santos Dias, } 1950\end{array}$ \\
\hline \multicolumn{2}{|l|}{ Argasid ticks } \\
\hline $\begin{array}{l}\text { Argas arboreus Kaiser, Hoogstraal \& Kohls, } 1964 \\
\text { Argas streptopelia Kaiser, Hoogstraal \& Horner, } 1970 \\
\text { Argas theilerae Hoogstraal \& Kaiser, } 1970 \\
\text { Argas walkerae Kaiser \& Hoogstraal, } 1969 \\
\text { Argas zumpti Hoogstraal, Kaiser \& Kohls, } 1968 \\
\text { Carios boueti (Roubad, \& Colas-Belcour, 1933) }\end{array}$ & $\begin{array}{l}\text { Carios confusus (Hoogstraal, 1955) } \\
\text { Carios cordiformis (Hoogstraal \& Kohls, 1967) } \\
\text { Carios faini (Hoogstraal, 1960) } \\
\text { Ornithodoros compactus Walton, } 1962 \\
\text { Ornithodoros porcinus Walton, } 1962 \\
\text { Ornithodoros zumpti Heisch \& Guggisberg, } 1953\end{array}$ \\
\hline
\end{tabular}

* Not listed in references 
TABLE 3 South African ticks, other than Rhipicephalus species, described by foreign researchers, for which additional descriptions have been produced by researchers in South Africa since 1908

\begin{tabular}{|c|c|}
\hline Species and authors* & Descriptions by researchers working in South Africa** \\
\hline Amblyomma hebraeum Koch, 1844 & Walker \& Olwage (1987) \\
\hline Amblyomma marmoreum Koch, 1844 & Theiler \& Salisbury (1959); Walker \& Olwage (1987) \\
\hline Amblyomma nuttalli Dönitz, 1909 & Theiler \& Salisbury (1959) \\
\hline Amblyomma sylvaticum (De Geer, 1778) & Theiler (1943a) \\
\hline Amblyomma tholloni Neumann, 1899 & Walker \& Olwage (1987) \\
\hline Aponomma exornatum (Koch, 1844) & Theiler (1945a) \\
\hline Aponomma latum (Koch, 1844) & Theiler (1945b) \\
\hline Aponomma transversale (Lucas, 1844) & Theiler (1945b) \\
\hline Dermacentor rhinocerinus (Denny, 1843) & Keirans (1993) \\
\hline Haemaphysalis aciculifer Warburton, 1913 & Theiler (1945c) \\
\hline Haemaphysalis elliptica (Koch, 1844) & Apanaskevich, Horak \& Camicas (2007) \\
\hline Haemaphysalis parmata Neumann, 1905 & Theiler (1945c) \\
\hline Haemaphysalis silacea Robinson, 1912 & Theiler (1945c) \\
\hline Hyalomma glabrum Delpy, 1949 & Apanaskevich \& Horak (2006) \\
\hline Hyalomma rufipes Koch, 1844 & Apanaskevich \& Horak (2008a) \\
\hline Hyalomma truncatum Koch, 1844 & Apanaskevich \& Horak (2008b) \\
\hline Ixodes alluaudi Neumann, 1913 & Theiler (1941) \\
\hline Ixodes bakeri Arthur \& Clifford, 1961 & Clifford, Walker \& Keirans (1976) \\
\hline Margaropus winthemi Karsch, 1879 & Walker \& Laurence (1973); Gothe (1967) \\
\hline Rhipicentor bicornis Nuttall \& Warburton, 1908 & Theiler (1961) \\
\hline Rhipicentor nuttalli Cooper \& Robinson, 1908 & Theiler (1961) \\
\hline
\end{tabular}

* Not listed in references

** Listed in references

TABLE 4 South African Rhipicephalus species described by foreign researchers, for which additional descriptions have been produced since 1908 by researchers in South Africa

\begin{tabular}{|l|l|}
\hline Rhipicephalus species and original authors* & Descriptions by researchers in South Africa** \\
\hline Rhipicephalus (Boophilus) decoloratus (Koch, 1844) & Gothe (1967); Arthur \& Londt (1973); Heyne (1986) \\
Rhipicephalus (Boophilus) microplus (Canestrini, 1887) & Gothe (1967); Londt \& Arthur (1975); Heyne (1986) \\
Rhipicephalus appendiculatus Neumann, 1901 & Walker, Norval \& Corwin (1981) \\
Rhipicephalus capensis Koch, 1844 & Walker, Keirans \& Horak (2000) \\
Rhipicephalus evertsi evertsi Neumann, 1897 & Walker et al. (2000) \\
Rhipicephalus follis Dönitz, 1910 & Walker et al. (2000) \\
Rhipicephalus gertrudae Feldman-Muhsam, 1960 & Walker et al. (2000) \\
Rhipicephalus kochi Dönitz, 1905 & Walker et al. (2000) \\
Rhipicephalus lunulatus Neumann, 1907 & Walker, Keirans, Pegram \& Clifford (1988); Walker et al. (2000) \\
Rhipicephalus maculatus Neumann, 1901 & Theiler \& Robinson (1953b); Walker et al. (2000) \\
Rhipicephalus muehlensi Zumpt, 1943 & Salisbury (1959); Walker et al. (2000) \\
Rhipicephalus nitens Neumann, 1904 & Walker et al. (2000) \\
Rhipicephalus oculatus Neumann, 1901 & Keirans, Walker, Horak \& Heyne (1993); Walker et al. (2000) \\
Rhipicephalus sanguineus (Latreille, 1806) & Pegram, Keirans, Clifford \& Walker (1987b); Walker et al. (2000) \\
Rhipicephalus simpsoni Nuttall, 1910 & Theiler 1949; Walker et al. 2000 \\
Rhipicephalus simus Koch, 1844 & Pegram, Walker, Clifford \& Keirans (1987c); Walker et al. (2000) \\
Rhipicephalus sulcatus Neumann, 1908 & Pegram, Clifford, Walker \& Keirans (1987a); Walker et al. (2000) \\
Rhipicephalus tricuspis Dönitz, 1906 & Walker et al. (1988; 2000) \\
Rhipicephalus turanicus Pomerantsev, 1936 & Pegram et al. (1987a); Walker et al. (2000) \\
Rhipicephalus zumpti Santos Dias, 1950 & Walker et al. (2000) \\
\hline
\end{tabular}

${ }^{*}$ Not listed in references

** Listed in references 
This was done after molecular and morphological studies by Murrell, Campbell \& Barker (2000) and Beati \& Keirans (2001) had indicated that the genus Rhipicephalus was paraphyletic in respect of the genus Boophilus. Murrell \& Barker (2003) later confirmed these name changes. The yellow dog tick of South Africa, previously lumped with Haemaphysalis leachi of North and East Africa, has been reinstated as Haemaphysalis elliptica, an old taxon originally described from the Cape of Good Hope by Koch in 1844 (Apanaskevich, Horak \& Camicas 2007). While the bont-legged ticks, to which sub-specific status within the Hyalomma marginatum species group had previously been assigned, have all been raised to specific status (Apanaskevich \& Horak 2008a). Furthermore the tick previously known as Hyalomma marginatum turanicum in South Africa has been reinstated as Hyalomma glabrum, the only Hyalomma with a strictly southern hemisphere, and with that a strictly South African distribution (Apanaskevich \& Horak 2006).

Three of the abovementioned ticks are of considerable veterinary importance in that $R$. (B.) decoloratus and $R$. (B.) microplus are the vectors of Babesia species, the cause of babesiosis or redwater in domestic cattle (De Vos, De Waal \& Jackson 2004), while $H$. elliptica, and not $H$. leachi, is now the only proven vector of Babesia canis rossi the cause of the virulent form of babesiosis encountered in domestic dogs in South Africa (Lewis, Penzhorn, Lopez-Rebollar \& De Waal 1996; Apanaskevich et al. 2007). A fourth member of this group, Hyalomma rufipes, is the principal vector in South Africa of the virus causing Crimean-Congo haemorrhagic fever in humans (Horak, Swanepoel \& Gummow 2002). The name changes are thus not only of academic importance, but of scientific concern as they are oft used in the literature concerning the diseases that they transmit and in which the correct use of taxonomic epithets is essential.

\section{ACKNOWLEDGEMENTS}

I have been fortunate in having two monographs to consult, namely those by Theiler (1962) and Walker (1991), and I pay tribute to both authors and to their attention to detail.

\section{REFERENCES}

All authors mentioned in the descriptive text have been listed, but only South African authors or foreign authors that worked in South Africa at the time at which they described particular tick species have been included in the list of references.
APANASKEVICH, D.A. \& HORAK, I.G. 2006. The genus Hyalomma Koch, 1844. I. Reinstatement of Hyalomma (Euhyalomma) glabrum Delpy, 1949 (Acari, Ixodidae) as a valid species with a redescription of the adults, the first description of its immature stages and notes on its biology. Onderstepoort Journal of Veterinary Research, 73:1-12.

APANASKEVICH, D.A., HORAK, I.G. \& CAMICAS, J-L. 2007. Redescription of Haemaphysalis (Rhipistoma) elliptica (Koch, 1844), an old taxon of the Haemaphysalis (Rhipistoma) leachi group from East and southern Africa, and of Haemaphysalis (Rhipistoma) leachi (Audouin, 1826) (Ixodida, Ixodidae). Onderstepoort Journal of Veterinary Research, 74: 181-207.

APANASKEVICH, D.A. \& HORAK, I.G. 2008a. The genus Hyalomma Koch, 1844. V. Re-evaluation of the taxonomic rank of taxa comprising the $H$. (Euhyalomma) marginatum group of species (Acari: Ixodidae) with redescription of all parasitic stages and notes on biology. International Journal of Acarology, 34:13-42.

APANASKEVICH, D.A. \& HORAK, I.G. 2008b. The genus Hyalomma. VI. Systematics of $H$. (Euhyalomma) truncatum and the closely related species, $H$. (E.) albiparmatum and $H$. (E.) nitidum (Acari, Ixodidae). Experimental and Applied Acarology, 44:115-136.

APANASKEVICH, D.A. \& HORAK, I.G. 2008c. Two new species of African Haemaphysalis ticks (Acari: Ixodidae), carnivore parasites of the H. (Rhipistoma) leachi group. Journal of Parasitology, 94:594-607.

ARTHUR, D.R \& LONDT, J.G.H. 1973. The parasitic life cycle of Boophilus decoloratus (Koch, 1844). Journal of the Entomological Society of Southern Africa, 36:87-116.

BEATI, L. \& KEIRANS, J.E. 2001. Analysis of the systematic relationships among ticks of the genera Rhipicephalus and Boophilus (Acari: Ixodidae) based on mitochondrial $12 \mathrm{~S}$ ribosomal DNA gene sequences and morphological characters. Journal of Parasitology, 87:32-48.

BEDFORD, G.A.H. \& HEWITT, J. 1925. Descriptions of two new species of ticks, with notes on rare and hitherto unrecorded species from South Africa. South African Journal of Natural History, 5:259-266.

BEDFORD, G.A.H. 1929. Notes on some South African ticks, with descriptions of three new species. Annual Report of the Director of Veterinary Services, Union of South Africa, 15: 493-499.

BEDFORD, G.A.H. 1931. Nuttalliella namaqua, a new genus and species of tick. Parasitology, 23:230-232.

BEDFORD, G.A.H. 1932. Description of Argas striatus, a new species of tick. $18^{\text {th }}$ Report of the Director of Veterinary Services and Animal Industry, Union of South Africa, 18:221-222.

BEDFORD, G.A.H. 1932. A synoptic check-list and host-list of the ectoparasites found on South African Mammalia, Aves and Reptilia ( $2^{\text {nd }}$ ed.). $18^{\text {th }}$ Report of the Director of Veterinary Services and Animal Industry, Union of South Africa, 18:223523.

CLIFFORD, C.M., THEILER, GERTRUD \& BAKER, MAUREEN, 1975. Ixodes (Afrixodes) drakensbergensis n. sp. from domestic and wild animals in Natal, Republic of South Africa. Onderstepoort Journal of Veterinary Research, 42:33-44.

CLIFFORD, C.M., WALKER, JANE B. \& KEIRANS, J.E. 1976. Ixodes (Afrixodes) bakeri Arthur \& Clifford, 1961 (Acarina: Ixodidae): descriptions of the male and immature stages from rodents and insectivores and notes on its biology in South Africa. Onderstepoort Journal of Veterinary Research, 43:105-112. 
CLIFFORD, C.M., WALKER, JANE B. \& KEIRANS, J.E. 1977. Ixodes (Afrixodes) neitzi, n. sp. (Acarina: Ixodidae) from the mountain reedbuck in South Africa. Onderstepoort Journal of Veterinary Research, 44:143-150.

DE VOS, A.J., DE WAAL, D.T. \& JACKSON, L.A. 2004. Bovine babesiosis, in Infectious diseases of livestock, edited by J.A.W. Coetzer \& R.C. Tustin. Cape Town: Oxford University Press.

DU TOIT, R. 1941. Description of a tick Rhipicephalus glabroscutatum, sp. nov. (Ixodidae), from the Karroo areas of the Union of South Africa. Onderstepoort Journal of Veterinary Science and Animal Industry, 16:115-118.

GOTHE, R. 1967. Ticks in the South African Zoological Survey Collection. Part XII. The genera Boophilus Curtice, 1891 and Margaropus Karsch, 1879. Onderstepoort Journal of Veterinary Research, 34:81-107.

HEYNE, HELOISE 1986. Differentiation of Boophilus decoloratus and Boophilus microplus. Journal of the South African Veterinary Association, 57:251-252.

HOOGSTRAAL, H., WALKER, JANE B. \& NEITZ, W.O. 1971. Notes on African Haemaphysalis ticks. VII. H. (Rhipistoma) hyracophila sp. nov. (Ixodoidea: Ixodidae), a parasite of hyraxes in South Africa. Journal of Parasitology, 57:417-425.

HOOGSTRAAL, H., KAISER, M.N., WALKER, JANE B., LEDGER, J.A., CONVERSE, J.D. \& RICE, R.C.A. 1975. Observations on the subgenus Argas (Ixodoidea: Argasidae: Argas). 10. A. (A.) africolumbae, n. sp., a Pretoria virus-infected parasite of birds in southern and eastern Africa. Journal of Medical Entomology, 12:194-201.

HORAK, I.G., CAMICAS, J.-L. \& KEIRANS, J.E. 2002. The Ixodidae, Amblyommidae and Nuttalliellidae (Acari: Ixodida): a world list of valid tick names. Experimental and Applied Acarology, 28:7-54.

HORAK I.G., SWANEPOEL R. \& GUMMOW, B. 2002. The distribution of Hyalomma spp. and human cases of CrimeanCongo haemorrhagic fever in South Africa, in Proceedings of the $10^{\text {th }}$ Conference of the Association of Institutions for Tropical Veterinary Medicine, Copenhagen, Denmark 20-23 August 2001: 501-509.

HORAK, I.G., MCKAY, I.J., HENEN, B.T., HEYNE, HELOISE, HOFMEYR, MARGARETHA D. \& DE VILLIERS, A.L. 2006. Parasites of domestic and wild animals in South Africa. XLVII. Ticks of tortoises and other reptiles. Onderstepoort Journal of Veterinary Research, 73:215-227.

KEIRANS, J.E., CLIFFORD, C.M. \& WALKER, JANE B. 1982. The Ixodes (Afrixodes) oldi group (Acari: Ixodidae) from subSaharan Africa with descriptions of five new species. Journal of Medical Entomology, 19:309-329.

KEIRANS, J.E. 1993. Dermacentor rhinocerinus (Denny, 1843) (Acari: Ixodida: Ixodidae): rediscription of the male, female and nymph and first description of the larva. Onderstepoort Journal of Veterinary Research, 60:59-68.

KEIRANS, J.E. WALKER, JANE B., HORAK, I.G. \& HEYNE, HELOISE 1993. Rhipicephalus exophthalmos sp. nov., a new tick species from southern Africa, and redescription of Rhipicephalus oculatus Neumann, 1901, with which it has hitherto been confused (Acari: Ixodida: Ixodidae). Onderstepoort Journal of Veterinary Research, 60:229-246.

KEIRANS, J.E. \& WALKER, JANE B. 1993. Rhipicephalus exophthalmos sp. nov., in KEIRANS, J.E., WALKER, JANE B. \& HORAK, I.G. 1993. Rhipicephalus exophthalmos sp. nov., a new tick species from southern Africa, and redescription of Rhipicephalus oculatus Neumann, 1901, with which it has hitherto been confused (Acari: Ixodida: Ixodidae). Onderstepoort Journal of Veterinary Research, 60:229-246.
LEWIS, B.D., PENZHORN, B.L., LOPEZ-REBOLLAR, L.M. \& DE WAAL, D.T. 1996. Isolation of a South African vector-specific strain of Babesia canis. Veterinary Parasitology, 63:9-16.

LONDT, J.G.H. \& ARTHUR, D.R. 1975. The structure and parasitic life cycle of Boophilus microplus (Canestrini, 1888) in South Africa (Acarina: Ixodidae). Journal of the Entomological Society of Southern Africa, 38:321-340.

MURRELL, A.N., CAMPBELL, J.H. \& BARKER, S.C. 2000. Phylogenetic analysis of the rhipicephaline ticks indicates that the genus Rhipicephalus is paraphyletic. Molecular Phylogenetics and Evolution, 16:1-7.

MURRELL, A. \& BARKER, S.C. 2003. Synonomy of Boophilus Curtice, 1981 with Rhipicephalus Koch, 1844 (Acari: Ixodidae). Systematic Parasitology, 56:169-172.

NAVA, S., GUGLIELMONE, A.A. \& MANGOLD, A.J. 2008. An overview of the systematics and evolution of ticks. Frontiers in Bioscience, in press.

PEGRAM, R.G., CLIFFORD, C.M., WALKER, JANE B. \& KEIRANS, J.E. 1987a. Clarification of the Rhipicephalus sanguineus group (Acari, Ixodoidea, Ixodidae). I. R. sulcatus Neumann 1908 and $R$. turanicus Pomarantsev, 1936. Systematic Parasitology, 10:3-26.

PEGRAM, R.G., KEIRANS, J.E., CLIFFORD, C.M. \& WALKER, JANE B. 1987b. Clarification of the Rhipicephalus sanguineus group (Acari, Ixodoidea, Ixodidae). II. R. sanguineus (Latreille, 1806) and related species. Systematic Parasitology, 10:27-44.

PEGRAM, R.G., WALKER, JANE B., CLIFFORD, C.M. \& KEIRANS, J.E. 1987c. Comparisons of populations of the Rhipicephalus simus group: $R$. simus, $R$. praetextatus and $R$. muhsamae (Acari: Ixodidae). Journal of Medical Entomology, 24:666-682.

SALISBURY, LOIS E. 1959. Ticks in the South African Zoological Survey Collection. Part X. Rhipicephalus mühlensi Zumpt. Onderstepoort Journal of Veterinary Research, 28:125-132.

THEILER, GERTRUD 1941. Ticks in the South African Zoological Survey Collection. Part I. Ixodes alluaudi Neumann, 1913, a primitive tick parasitic on shrews. Onderstepoort Journal of Veterinary Science and Animal Industry, 17:51-60.

THEILER, GERTRUD 1943. Ticks in the South African Zoological Survey Collection. Part II. Onderstepoort Journal of Veterinary Science and Animal Industry, 18:85-89.

THEILER, GERTRUD 1945a. Ticks in the South African Zoological Survey Collection. Part III. The ornate Aponommas. Onderstepoort Journal of Veterinary Science and Animal Industry, 20:165-178.

THEILER, GERTRUD 1945b. Ticks in the South African Zoological Survey Collection. Part IV. The inornate Aponommas. Onderstepoort Journal of Veterinary Science and Animal Industry, 20:179-190.

THEILER, GERTRUD 1945c. Ticks in the South African Zoological Survey Collection. Part V. Three African haemaphysalids parasitic on domestic stock. Onderstepoort Journal of Veterinary Science and Animal Industry, 20:191-207.

THEILER, GERTRUD 1949. Ticks in the South African Zoological Survey Collection. Part VI. Little known African rhipicephalids. Onderstepoort Journal of Veterinary Science and Animal Industry, 21:253-300.

THEILER, GERTRUD \& ZUMPT, F. 1949. Description of new species. Rhipicephalus (s. str.) arnoldi Theiler \& Zumpt, n. sp., in ZUMPT, F. 1949. Preliminary study to a revision of the genus Rhipicephalus Koch. Key to the adult ticks of the genus 
Rhipicephalus Koch and description of two new species. Moçambique, 60:57-123.

THEILER, GERTRUD \& ROBINSON, BRITHA N. 1953. Ticks in the South African Zoological Survey Collection. Part VII. Six lesser known African rhipicephalids. Onderstepoort Journal of Veterinary Research, 26:93-136.

THEILER, GERTRUD 1959. Ticks in the South African zoological survey collection-Part XI-Ornithodoros eboris n. sp. Onderstepoort Journal of Veterinary Research, 28:145-153.

THEILER, GERTRUD \& SALISBURY, LOIS E. 1959. Ticks in the South African Zoological Survey Collection. Part IX. "the Amblyomma marmoreum group". Onderstepoort Journal of Veterinary Research, 28:47-124.

THEILER, GERTRUD 1961. A contribution to the knowledge of African Ixodidae. The genus Rhipicentor. Revue de Zoologie et de Botanique Africaines, 66:297-308.

THEILER, GERTRUD 1962. The Ixodoidea parasites of vertebrates in Africa south of the Sahara (Ethiopian region). Project S 9958. Report to the Director of Veterinary Services, Onderstepoort. Mimeographed.

WALKER, JANE B. \& LAURENCE, B.R. 1973. Margaropus wileyi sp. nov. (Ixodoidea, Ixodidae), a new species of tick from the reticulated giraffe. Onderstepoort Journal of Veterinary Research, 40:13-22.

WALKER, JANE B., NORVAL, R.A.I. \& CORWIN, M.D. 1981. Rhipicephalus zambeziensis sp. nov., a new tick from eastern and southern Africa, together with a rediscription of Rhipicephalus appendiculatus Neumann, 1901 (Acarina, Ixodidae). Onderstepoort Journal of Veterinary Research, 48: 7-104.

WALKER, JANE B. \& OLWAGE, A. 1987. The tick vectors of Cowdria ruminantium (Ixodoidea, Ixodidae, genus Amblyom- ma) and their distribution. Onderstepoort Journal of Veterinary Research, 54: 353-379.

WALKER, JANE B., KEIRANS, J.E., PEGRAM, R.G. \& CLIFFORD, C.M. 1988. Clarification of the status of Rhipicephalus tricuspis Dönitz, 1906 and Rhipicephalus lunulatus Neumann, 1907 (Ixodoidea, Ixodidae). Systematic Parasitology, 12:159-186.

WALKER, JANE B. 1990. Two new species of ticks from southern Africa whose adults parasitize the feet of ungulates: Rhipicephalus lounsburyi n. sp. and Rhipicephalus neumanni $\mathrm{n}$. sp. (Ixodoidea, Ixodidae). Onderstepoort Journal of Veterinary Research, 57:57-75.

WALKER, JANE B. 1991. A review of the ixodid ticks (Acari: Ixodidae) occurring in southern Africa. Onderstepoort Journal of Veterinary Research, 58:81-105.

WALKER, JANE B., KEIRANS, J.E. \& HORAK, I.G. 2000. The genus Rhipicephalus (Acari, Ixodidae): a guide to the brown ticks of the world. Cambridge: Cambridge University Press.

WALKER, JANE B. \& HORAK, I.G. 2000. Rhipicephalus oreotragi, sp. nov., in WALKER, JANE B., KEIRANS, J.E. \& HORAK, I.G. 2000. The genus Rhipicephalus (Acari, Ixodidae): a guide to the brown ticks of the world. Cambridge: Cambridge University Press.

WALKER, JANE B. \& HORAK, I.G. 2000. Rhipicephalus warburtoni sp. nov., in WALKER, JANE B., KEIRANS, J.E. \& HORAK, I.G. 2000. The genus Rhipicephalus (Acari, Ixodidae): a guide to the brown ticks of the world. Cambridge: Cambridge University Press.

ZUMPT, F. 1943. Rhipicephalus aurantiacus Neumann und ähnliche Arten. VIII. Vorstudie zu einer Revision der Gattung Rhipicephalus Koch. Zeitschrift für Parasitenkunde, 13:102117. 